Pesq. Vet. Bras. 30(1):87-93, janeiro 2010

\title{
Development of IgY antibodies in chickens and IgG in rabbits immunized against proteins of Pythium insidiosum isolated from horses in the state of Rio de Janeiro ${ }^{1}$
}

\author{
Maria Fabíola Nunes Rangel², Luciana da Silva Lemos², Cláudia Maria Costa \\ de Almeida², Lério Gama Sales ${ }^{2}$ e Olney Vieira-da-Motta ${ }^{2}$
}

\begin{abstract}
Nunes Rangel M.F., Lemos L.S., Almeida C.M.C., Sales L.G. \& Vieira-daMotta O. 2010. Development of Polyclonal IgY antibodies in chickens and IgG in rabbits immunized against proteins of Pythium insidiosum isolated from horses in the state of Rio de Janeiro. Pesquisa Veterinária Brasileira 30(1):87-93. Micologia Veterinária do Setor de Doenças Infectocontagiosas, Laboratório de Sanidade Animal do Centro de Ciências e Tecnologias Agropecuárias, Universidade Estadual do Norte Fluminense Darcy Ribeiro, Av. Alberto Lamego 2000, Horto, Campos dos Goytacazes, RJ 28013-602, Brazil. E-mail: olney@uenf.br

Pythiosis is caused by Pythium insidiosum and the occurrence of disease in horses was described in the North and Northwest State of Rio de Janeiro, Brazil. The disease was described in cattle, sheep, humans, and horses in different states and regions across the country. This paper describes the development of IgY and IgG polyclonal antibodies, in chicken and rabbits, respectively against proteins extracted from kunkers and hyphae of $P$. insidiosum from affected horses. The proteins were recognized by chicken, rabbit and horse antibodies by immunodiffusion and Western blot against majority bands of 27 and $43 \mathrm{KDa}$, and titrated by ELISA. The antibodies IgY developed by the first time against Brazilian strains of $P$. insidiosum may represent a valuable tool in the detection of antigens of the pathogen and contribute to further studies aimed at immunotherapy and knowledge about this disease in endemic areas in Rio de Janeiro and in Brazil.
\end{abstract}

INDEX TERMS: Pythiosis, Pythium insidiosum, diseases of horses, IgY and IgG antibodies.

RESUMO.- [Desenvolvimento de Anticorpos IgY em galinhas e IgG em coelhos imunizados contra proteínas de Pythium insidiosum isolado de equinos no Estado do Rio de Janeiro, Brasil.] Pitiose é causada por Pythium insidiosum e a doença foi descrita em equinos no Norte e Noroeste do Estado do Rio de Janeiro, Brasil. A doença foi descrita em bovinos, ovelhas, humanos e cavalos em diferentes estados e regiões do país. Este trabalho descreve o desenvolvimento de anticorpos policlonais, IgY e IgG, em galinha e coelho, respectivamente, contra proteínas extraídas de kunkers e hifas de $P$. insidiosum de cavalos doentes. As proteínas foram reconheci-

\footnotetext{
${ }^{1}$ Received on July 26, 2009.

Accepted for publication on September 10, 2009.

${ }^{2}$ Laboratório de Sanidade Animal, Hospital Veterinário, Universidade Estadual do Norte Fluminense Darcy Ribeiro (UENF), Av. Alberto Lamego 2000, Horto, Campos dos Goytacazes, RJ 28013-602, Brasil. *Corresponding author: olney@uenf.br
}

das por anticorpos de galinha, coelho e cavalos contra as bandas majoritárias de 27 e $34 \mathrm{KDa}$ em imunodifusão e Western blot tituladas por ELISA. Os anticorpos IgY desenvolvidos pela primeira vez contra cepas brasileiras de $P$. insidiosum podem representar um valioso instrumento na detecção de antígenos de patógenos e contribuem para novos estudos baseados na imunoterapia e no entendimento sobre esta doença em áreas endêmicas no Rio de Janeiro e em todo o país.

TERMOS DE INDEXAÇÃO: Pitiose, Pythium insidiosum, doenças de equinos, anticorpos IgY e IgG.

\section{INTRODUCTION}

Pythiosis is a granulomatous disease that affects animals and humans, caused by Pythium insidiosum, Oomycetes belonging to family Pythiaceae, with greater incidence in tropical and subtropical regions and the only described species of Pythium capable of causing disease in mammals (De Cock et al. 1987). 
The epidemiology and distribution of the genus Pythium was described in soil and aquatic environments around the world and the life cycle of $P$. insidiosum occurs necessarily in flooded environment. This organism affects several species of animals including horses, cats, dogs, cattle, sheep, camels, bears, and birds resulting in various pathological conditions (Pier et al. 2000, Wellehan et al. 2004, Berryessa et al. 2008, Pesavento et al. 2008). In Brazil, the disease in horses was described in northern state of Rio de Janeiro, Brazil (Reis Jr. et al. 2003), in cattle in flooded areas of the states of Mato Grosso do Sul, and Rio Grande do Sul (Santurio et al. 2004, Gabriel et al. 2008, Grecco et al. 2009), and in flocks of sheep, in the state of Paraíba, northeastern Brazil (Tabosa et al. 2004). Equine pythiosis is characterized by localized inflammatory lesions containing necrotic centers called kunkers, affecting different parts of the animals body. The disease is classified according to the injured area as intestinal, cutaneous, subcutaneous, vascular, visceral and ocular pythiosis (Chaffin 1995). In humans, the disease causes deformities if not treated in time and its occurrence was reported in Thailand (Thianprasit 1996), and recently, in the leg of a man in the state of São Paulo, Brazil (Bosco et al. 2005); the disease form in the eye is described mostly in persons from rural areas (Kunavisarut et al. 2003). Techniques for experimental immunotherapy of pythiosis in rabbits (Santurio et al. 2003), in naturally infected dogs and horses in North America (Mendoza et al. 2003) were developed, suggesting that the disease may be associated with a response of Th2 type in the course of the disease and Th1 type, after the cure (Mendoza et al. 2003). Geographical divergent strains of this agent may result in different profiles of protein patterns recognition by western blot, independently of animal species, including human (Chindamporn et al., 2009). The antibodies developed in birds, named IgY, may have several applications in veterinary medicine, as in the diagnosis of bacterial proteins (Vieira-daMotta et al. 2001a, Almeida et al. 2003), immunotherapy on viral diseases in dogs with parvovirus (Van Nguyen et al. 2006), as prophylactic against infectious diarrhea in newborn calves (Erhard et al. 1997), potential use in cases by bothropic and crotalic poison (Almeida et al. 1998), and diagnosis in forensic elucidation (Brunda et al. 2006). This technology has as one of its main advantages the phylogenetic characteristics and production in large scale at low cost (Warr et al. 1995, Carlander et al. 1999). Aiming the development of an alternative tool for diagnosis of pithyosis, this work presents IgY from chicken and IgG from rabbit recognizing proteins from kunkers and hyphae of $P$. insidiosum isolated in endemic area of Rio de Janeiro State, Brazil.

\section{MATERIALS AND METHODS}

Collection of samples for culture and histology. The horses, totalizing 15 animals with clinical signs of pythiosis, were contained, anesthetized and samples from the lesions were transported at room temperature to laboratory processing. Samples of kunkers were previously placed in vials with a solution of sterile saline containing cyclohexamide ${ }^{3}(0.04 \mathrm{~g} / \mathrm{liter})$ and gentamicin ${ }^{4}(1.0 \mathrm{mg} / \mathrm{l})$ for culture. Tissue samples for histological examination were placed in vials containing $10 \%$ neutral buffered formalin solution. Culture of fresh kunkers from skin samples was carried out in Brain Heart Agar (BHA) agar ${ }^{5}$ supplemented by $5 \%$ sterile defibrinated sheep blood in plates, for a minimum of three days incubation at $37^{\circ} \mathrm{C}$.

Extraction of proteins. At the laboratory, samples of kunkers remained in the transport solution for 30 minutes in a magnetic hub, after being washed for three times with distilled water. Further, a mass of kunkers was kept at $4^{\circ} \mathrm{C}$ for $36 \mathrm{~h}$ in the antibiotic solution, and the liquid phase was discarded for subsequent grinding in liquid nitrogen with a pistil; $40 \mathrm{ml}$ phosphate buffer saline PBS $(\mathrm{pH}$ 7.4) were added; the material was kept at room temperature for two hours and centrifuged for 5 minutes at $4,500 \times g$, and the supernatant was collected, frozen in liquid nitrogen bath, lyophilized completely. The resulted phase in the precipitate was stored in a freezer at $-20^{\circ} \mathrm{C}$. The lyophilized material was resuspended in $5.0 \mathrm{~mL}$ of depyrogenated water, originating samples concentrated 8 times. To calculate the concentration of protein, the bicinchoninic acid $(\mathrm{BCA})^{3}$ kit was used, according to manufacturer's indications. For further supplementary extraction of protein, the precipitate material was suspended in $8 \mathrm{M}$ urea denaturing buffer (UDB), resting for two hours under refrigeration and then processed as described for extraction by PBS. For extraction of proteins from mycelium, fresh kunkers were placed in flasks containing sterile distilled water added by $1.0 \mathrm{~g} / \mathrm{mL}$ of gentamicin ${ }^{3}$ resting at room temperature for at least one week. The mass of hyphae $(1.5 \mathrm{~g})$ was collected and crushed in liquid nitrogen, re-suspended in $1.0 \mathrm{~mL}$ UDB, sonicated in five rounds of $80 \mathrm{~W}$ pulses of three minutes, and centrifuged at $4,500 \mathrm{xg}$ for 10 minutes at room temperature, and protein concentration calculated.

Histology. Samples containing kunkers were processed routinely for histopathology and stained with hematoxylin and eosin (HE) and Grocott-Gomori silver methanamine.

Gel electrophoresis SDS-PAGE. This step was performed by standardized methodology in gel SDS-PAGE ( $5 \%$ and $12 \%)$, according to Laemmli (1970). The gels were stained in Comassie brilliant blue (Bromophenol blue 0.025\%, 10\% glycerol, $0.06 \mathrm{M}$ Tris $\mathrm{pH} 6,8$, SDS 2\%, 5\% â-mercaptoethanol).

Immunization of animals. Three Rhode Island Red breed chickens, four weeks of age each were used and kept ad libitum in cages at University facilities (Vieira-da-Motta et al. 2001a,b) free of disease and maintained until laying eggs. They were immunized with $200 \mathrm{mg}$ of total protein injected in the muscle of the chest, containing the homogenized antigens with complete Freund's adjuvant $(F A)$ for first immunization and incomplete FA for subsequent immunizations, and completed to $1,0 \mathrm{~mL}$ final volume with PBS solution (pH 7.2). A total of three immunizations were performed at intervals of 21 days. In order to obtain rabbit antisera against the agent, two New Zealand rabbits, ranging 8 to 12 weeks of age, were immunized subcutaneously in the upper cervical region, following the immunization protocol for chicken. Pre-immune serum samples from chicken and rabbits and egg yolks samples from chicken were collected for negative controls before the first immunization and stored in a freezer at $-20^{\circ} \mathrm{C}$. All animals were kept in proper conditions according to standards required by the University bioethics committee and according to

\footnotetext{
${ }^{3}$ Sigma-Aldrich, 3050 Spruce Street, St Louis, MO 63103, USA, http:/ /www.sigma-aldrich.com

${ }^{4}$ Invitrogen Corporation, Invitrogen Corporation 1600 Faraday Avenue, PO Box 6482, Carlsbad, CA 92008, USA.

${ }^{5}$ Acumedia, Neogen Corporation, 620 Lesher Place, Lansing, MI 48912, USA.
} 
a previous study (Remfry 1985). At the end of the experiments, all animals used for antibodies production were sent to a local farmer and remained alive.

Purification of antibodies IgY from egg yolks. The yolks were treated and used as described by other authors (Brunda et al. 2006) with modifications. The egg yolks were washed with PBS pH 7.2, the contents removed by aspiration with Pasteur pipette and transferred to sterile flasks. The material was diluted at a ratio of 1:10 in distilled water and maintained for 14-16 $\mathrm{h}$ at $4^{\circ} \mathrm{C}$. Further a centrifugation step at $14.000 \times \mathrm{g}$ for $30 \mathrm{~min}$ at $4^{\circ} \mathrm{C}$, discarded the insoluble part, added $19 \%$ of sodium sulphate $(\mathrm{w} /$ $v)^{6}$ to the supernatant, and kept at room temperature, under constant stirring for $2 \mathrm{~h}$ and followed by another centrifugation step at $14.000 \times g$ for 30 minutes in refrigerated centrifuge ${ }^{7}$. The precipitate containing the solutions of purified yolk $\lg Y$ was resuspended in PBS and obtained a $5 x$ concentrated volume of yolk compared to the original solution; dialyzed at $4^{\circ} \mathrm{C}$ against distilled water for two days with water changed twice a day. The final material was half lyophilized and stored $-20^{\circ} \mathrm{C}$ and half was filter-sterilized, with aliquots stored at $4^{\circ} \mathrm{C}$.

\section{Immunological methods}

Ouchterlony precipitation test. Samples of sera from animals and extracted proteins from kunkers were tested in acrylic Petri dishes of $5.0 \mathrm{~cm}$ in diameter (Falcon, USA) containing $1.2 \%$ agar Noble (Difco, USA), and added a solution of thimerosal ${ }^{3}$ to a final $1: 10000(\mathrm{v} / \mathrm{v})$ concentration. Serum samples diluted 1:2 (PBS: serum v/v) and was applied in $0.5 \mathrm{~cm}$ diameter wells and total proteins deposited in $0.25 \mathrm{~cm}$ diameter central well. After incubation at $37^{\circ} \mathrm{C}$ in a moist chamber for 24 hours, the agar was stained with Coomassie brilliant blue, as described by Su \& Wong (1995).

Western blot. The immunoblotting assay was performed according to Almeida et al. (1998) with some modification. All SDS-PAGE gels were prepared in duplicates. The transfer to nitrocellulose membranes ${ }^{8}$ previously soaked in washing solution (WS)(100mM Tris, $1.5 \mathrm{M} \mathrm{NaCl}, 0.5 \%$ Tween-20 and TST-20) was performed in phosphate buffer $(1 \mathrm{M}, \mathrm{pH} 7.4)$ and completed on Mini-Trans-Blot Eletrophoretic Transfer Cell System ${ }^{8}$ during 2 hours at a constant voltage of $10 \mathrm{~V}$. The membranes were blocked (TST-20 $+0.3 \%$ of milk powder solution), washed twice in WS and incubated under refrigeration in the presence of 1:1000 primary antibodies overnight in a constant shaking. After a fourwash step, the membranes were incubated for two hours with 1:2000 secondary goat anti-chicken antibodies ${ }^{3}$ in a constant shaking, at room temperature (RT). Finally, antibodies reacting bands were developed $\mathrm{RT}$ in proper solution [40mM Tris $\mathrm{HCl} \mathrm{pH}$ 7.4, 100 mM imidazole, $\mathrm{H}_{2} \mathrm{O}_{2}$ 30R, DAB (3,3 diaminobenzidine ${ }^{3}$, in the presence of $\mathrm{H}_{2} \mathrm{O}_{2}$ or several minutes and dried at $37^{\circ} \mathrm{C}$. An american sample of IgG anti-P. insidiosum developed in rabbit was used as positive control for this experiment.

Antibodies titration by ELISA. The antigens (50mg/well) diluted in buffer carbonate/bicarbonate $\mathrm{pH} 9.6$ and $50 \mathrm{~mL}$ were distributed in 96 flat well plates (Corning, USA), previously washed in PBS $\mathrm{pH} 7.2$, and primary $\lg \mathrm{Y}$ antibodies in dilutions of $1: 100$ to $1: 3600$ were used, for detection and titration of anti-

\footnotetext{
${ }^{6}$ Merck Kgaa, Frankfurter Str. 250, 64293 Darmstadt, Germany.

7 MR23i Jouan, Thermo Fisher Scientific Inc., 81 Wyman Street, Waltham, MA 02454-9046, USA.

${ }^{8}$ Bio-Rad Laboratories, Inc., 2000 Alfred Nobel Drive, Hercules, CA 94547, USA.
}

Pythium IgY, 0.05mL. In the following step, secondary antibodies IgG goat anti-chicken ${ }^{3}$ and rabbit IgG anti-rabbit ${ }^{3}$ peroxidase conjugate were used at 1:2000 dilutions. As negative controls, pre-immune egg yolk IgY and IgG from rabbit serum were used. Tests were revealed in acid buffer (revealing solution), containing OPD and in $3 \mathrm{~N} \mathrm{H}_{2} \mathrm{SO}_{4}$ stop solution..

\section{RESULTS}

\section{Culture}

Growth of delicate medium adhered whitish colonies in BHA blood agar was observed from kunkers after three days of culture at $37^{\circ} \mathrm{C}$ (Fig.1).

\section{Development of antibodies}

Extraction of protein for PBS and immunological tests. Reading the total proteins in the material showed concentration $2.0 \mathrm{mg} / \mathrm{mL}$ of extracted material from kunkers (Fig.2) and $1.0 \mathrm{mg} / \mathrm{mL}$ of extracted material from the growing hyphae (data not shown) of Pythium insidiosum.

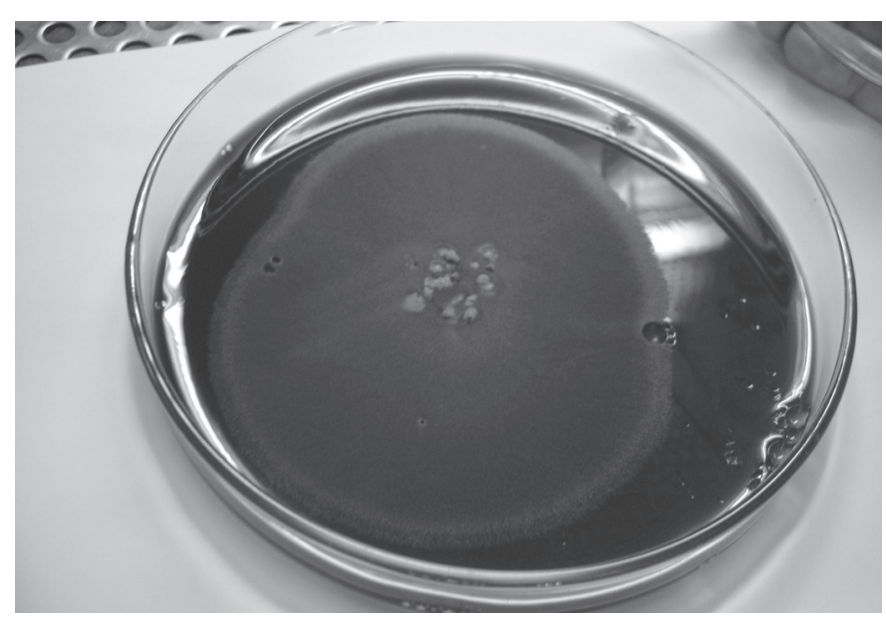

Fig.1. Culture of Pythium insidiosum kunkers (center) in Brain Heart Agar. Thin, adherent, delicate white opaque hyphae growth after three days incubation at $37^{\circ} \mathrm{C}$.

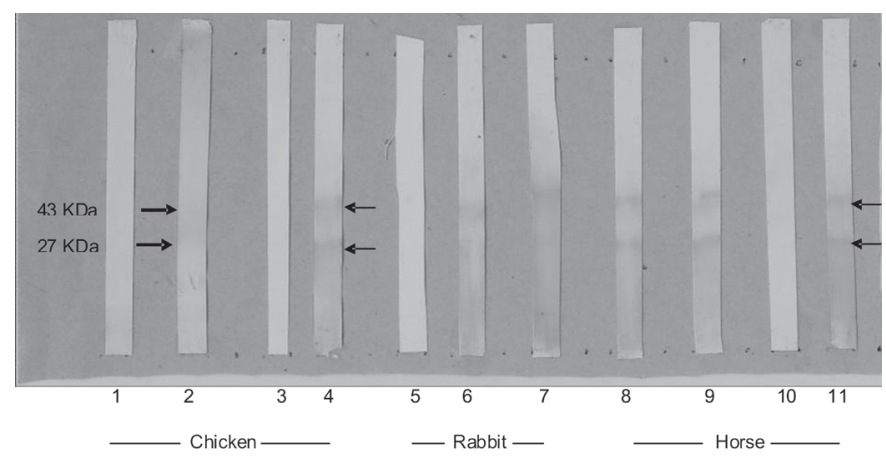

Fig.2. Immunoblotting: immobilized protein of Pythium insidiosum in developed membranes with different antibodies sources. Membranes 1-2: purified IgY from yolk of pre- and post-immune chicken, respectively; Membranes 3-5: serum pre- and post-immune rabbit, and positive control rabbit serum, respectively; Membranes 6-9: representative samples sera from diseased horses. Sample 8 from diseased horse did not react by using this test. 

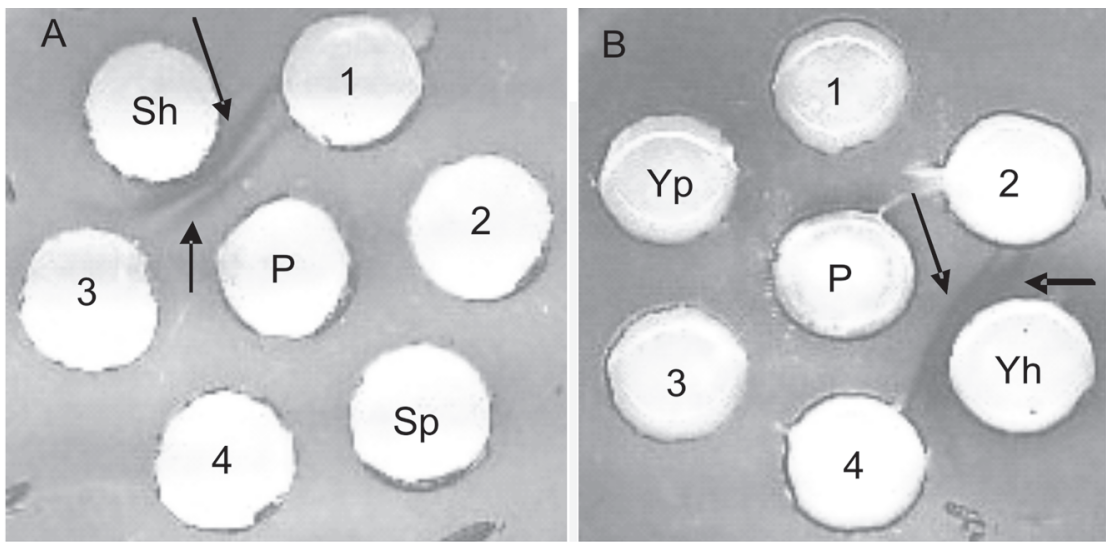

Fig.3. Representative imunodiffusion in 1.2\% noble agar. Panels A and B illustrate reaction with present antibodies in samples of chicken serum and yolk of $\lg Y$, respectively, immunized with protein of kunker of Pythium insidiosum. Wells

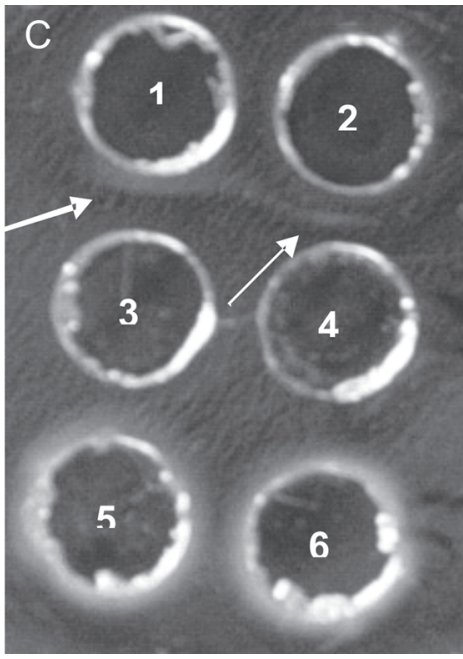
1, 2, 3 and 4: PBS; Sh and Sp: hyperimmune and pre-immune IgY serum, respectively, and Yp and Yh: preimmune and hyperimmune IgY yolk, respectively. The arrows indicate the precipitation lines in the reaction. Panel $\mathrm{C}$ shows reaction with serum samples from horse with pythiosis, the arrows indicate the point of reaction and formation of a precipitation line between the wells 1 and 2 with serum of positive diseased animal and the wells containing kunkers proteins extracted by PBS undiluted (3), and diluted buffer 1:2 (v/v PBS / protein extract) (4); wells 5 and 6 sera from negative horses (control).
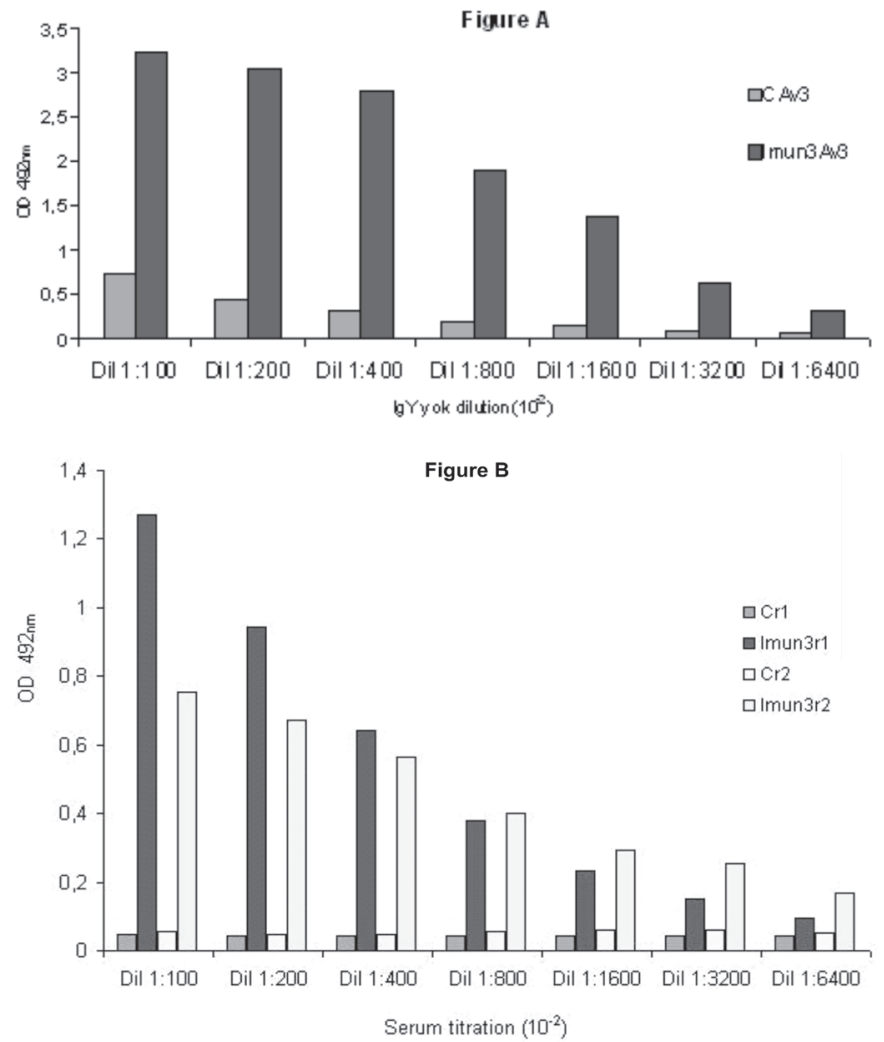

Fig.4. (A) ELISA titration of IgY from chickens immunized against proteins extracted from kunkers of Pythium insidiosum strains. Abbreviations: Cav3: IgY extracted from controls yolks; Imun3Av3: IgY extracted from egg yolks of immunized chickens. (B) ELISA titration of IgG from rabbits immunized against proteins extracted from kunkers of Pythium insidiosum strains. Abbreviations: $\mathrm{Cr} 1$ and $\mathrm{Cr} 2$ : serum Control from rabbit 1 and serum Control from rabbit 2; Imun3r1: Serum from of third immunization from rabbit 1. Imun3r2: Serum from third immunization of rabbit 2
Immunoblotting. Figure 2 is representative of the membrane for immunoblotting with antibodies from egg yolk ( $\operatorname{lgY})$, serum from birds, rabbits, and equines, and the profile of recognition of bands by antibodies from immunized rabbits and birds were similar to samples of sera from equines with pythiosis. Although animal from sample 10 was clinically ill, the corresponding sample showed negative, i.e., did not recognize the antigen. The rabbit positive control serum sample (American sample) and serum from rabbits presently immunized showed similar pattern of either of the antibodies developed.

Titration of antibodies present in serum and egg yolk of chickens. By ELISA assay, the developed IgY antibodies from chickens and IgG from rabbits, recognized the antigens from the corresponding titration in concen-

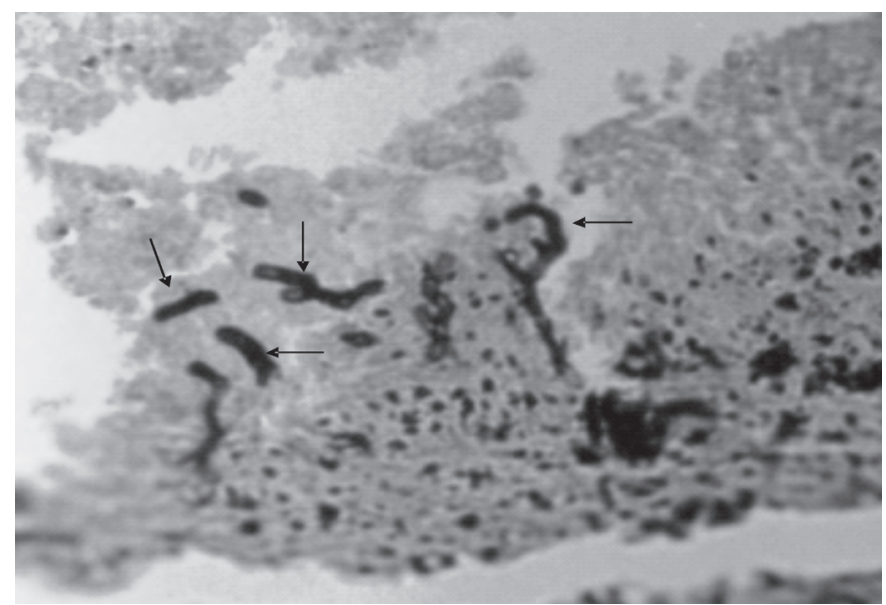

Fig.5. Histopatology showing hyphae (black arrows) of Pythium insidiosum in kunkers from a lesion in skin and subcutaneous tissue of the forelimb of a horse. Grocott-Gomori silver methanamine stain, obj.40x. 
trations ranging from 1:100 to 1: 6400 . The graphics of Figures $4 a$ and $4 b$ are representative of the titration profile of polyclonal antibodies.

Ochterlony precipitation test - Immunodiffusion. Fig. 3 shows two lines in wells containing IgY antibodies samples from post immunization serum and egg yolk (panels A and B) and a single line of precipitin in the sera of health and diseased equines (panel C).

\section{Histopathology}

Histological examination of samples revealed hyphae of the agent from samples of cutaneous tissue after Grocottt-Gomori silver methnamine staining, consistent with $P$. insidiosum (Fig.5).

\section{DISCUSSION AND CONCLUSIONS}

This paper describes the development of IgY antibodies in birds immunized with the protein of kunkers from Pythium insidiosum. The immunological aspects of pythiosis were discussed and suggested that in horses the responses differed according to the disease. In affected animals, the response was to Th2 type, while in cured ones the response was to type Th1 (Mendoza et al. 2003). With reference to the latter, the success of immunotherapy in horses in different stages of infection, including animals in the chronic phase of disease, was attributed to cytoplasmic antigens, that were included in the vaccine formulation, which was composed of previously exposed antigens (Mendoza et al. 1992a, 2003). In the present study, antigens of strains of kunkers occured in the region were isolated and the material recognized by the techniques of ELISA immunodiffusion and immunoblotting in samples of sera from infected horses and animals experimentally immunized with proteins of the agent. Titration by ELISA test showed consistent results for the technique. The results of immunoblotting indicated that two immunodominant bands of approximately $27 \mathrm{KDa}$ and 43 showed the best profile for recognition, but other bands of different molecular weight were visible on SDS-PAGE gel (data not shown). Mendoza et al. (1992b) identified three immunodominant bands $(28,30$ and $32 \mathrm{KDa}$ ) in antigenic material from hyphae, which reacted with the serum of horses with pythiosis and confirm the hypothesis that all strains of $P$. insidiosum are antigenically similar, regardless of source of origin or geographical area. Those authors worked with strains from horses in Costa Rica, United States, Japan, Australia, and a strain extracted from Thai human carriers of the disease. However, the used methodologies were different between the two works. In this study, the used strains are all from the north and northwest of Rio de Janeiro state, previously reported by other authors (Reis $\mathrm{Jr}$ et al. 2003). A similar result was observed by immunodiffusion with more than a precipitin line and with sera from equines with pythiosis (Mendoza \& Alfaro 1986). In this work, the results obtained by the technique of immunodiffusion, except part of the samples used as negative controls (pre-immunization), showed the recognition of two antigens by antibodies of birds, which could match the dominant revealed two main bands in SDS gel -PAGE. Furthermore, sera obtained from equines recognized a single line. The differences obtained in the electrophoretic patterns of isolated proteins could arise from methodologies and sources of used samples and possibly by differences between the exposed epitopes by bodies in different conditions of growth. In addition, the material extracted from colonies of the agent in this work for PBS and subsequent sonication was also recognized by antibodies in the three immunodiagnostic techniques, corroborating the results of other authors and immunological nature of the used material as antigen source. The polypeptides differ in their ability to stimulate an antibody response when administered in mixtures, as well as stimulating the immune response, which is exercised by antigens of higher molecular weight. In the formation of antibodies, usually prevail (Dong et al. 2003) to those of lower molecular weight. The protein bands present in material extracted from $P$. insidiosum ranging in molecular weight. The poultry and rabbit antibodies recognized similar intensities in both bands majority, although the serum sample of post-immune birds has revealed more weakly (Fig.1, membrane 2), by immunoblotting. In serum samples from human origin was an ample scope for recognition of protein bands by immunoblotting, with a predominance of molecular weight bands between 23 to $35 \mathrm{KDa}$. This technique regarded as a major and more sensitive in detecting antigens against the agent (Vanittanakom et al. 2004). Another study about the development of $\lg Y$ and $\operatorname{lgG}$ antibodies against octapeptide cholecystokinin (CCK-8) showed that the shorter peptide sequences were more recognized by antibodies of birds, compared with the ones of longer sequence (Schade et al. 1996). IgY antibodies developed against enterotoxins of molecular weight in the range between 20 and $30 \mathrm{KDa}$ of Staphylococcus aureus of bovine origin showed inhibitory activity in the growth of the bacteria (Vieira-da-Motta et al. 2001a). Davis et al. (2006) identified proteases with molecular weights between 24 and $38 \mathrm{KDa}$ of three species of Pythium, including the pathogen $P$. insidiosum. IgY developed antibodies against snake venom of Naja predominantly recognized proteins of molecular lower weight in the range between 10 to 29 $\mathrm{KDa}$, while IgG antibodies from rabbit mainly recognized those ones in the range 46 to $77 \mathrm{KDa}$ (Brunda et al. 2006). Krajaejum et al. (2006) described one of $74 \mathrm{KDa}$ immunodominant antigen recognized by sera samples of patients with pythiosis in Thailand, by using the immunoblotting technique, working with sera of equine origin. The approach used in this work to develop polyclonal antibodies anti- $P$. insidiosum in birds was similar to that used to obtain purified by affinity IgY developed against snake detoxified venom of Naja (Brunda et al. 2006). The difference patterns of antibodies against proteins of molecular weight in different bands may result from the phylogenetic difference of animal model used to develop them and also the difference of the two structural proteins, such as the lack 
of folding in the region compared IgY with the molecule of IgG (Carlander et al. 1999). Others (Chindamporn et al., 2009) have suggested that differences in antibodies patterns recognition by western blot from sera of different species from different geographic areas, including human antibodies, against $P$. insidiosum may be attributed to a lack of methodology standardization, and showed that a protein with approximate $28 \mathrm{KDa}$-molecular weight was recognized, but was not observed by others in Brazil, working with sera from naturally infected horses and cattle and experimentally inoculated rabbits (Leal et al 2005) Here chickens antibodies have recognized an approximate $27 \mathrm{KDa}$-molecular weight protein, also recognized by horses and rabbits. Taking into account the phylogenetic divergence among birds and mammals, these results suggest that protein pattern ranging $20-40 \mathrm{KDa}$ may constitute the main target antigens of $P$. insidiosum independent of the species infected. Moreover, kunkers may serve as material for further studies of the agent in the area in question. The IgY antibodies recognized the proteins obtained in this work by immunoblotting in a similar pattern of IgG from the serum of equines with pythiosis and from rabbits immunized. Informations about developed antibodies against $P$. insidiosum in egg yolks are not available in the literature to date, considered so unique in the world. Considering the phylogenetic difference between birds and mammals, the antibodies developed against the pathogen $P$. insidiosum may represent a valuable tool in the diagnosis of pythiosis in the region and in the country.

Acknowledgments.- To the farmers who kindly allowed access to the animals for collecting material. To Dr Janildo Ludolf Reis Jr from UnB/Brazil, for sending us the rabbit antiserum kindly provided by $\mathrm{Dr}$ J. Newton from the University of Alabama. To Fundação Carlos Chagas Filho de Amparo a Pesquisa do Estado do Rio de Janeiro (FAPERJ) for financial support (Grants FAPERJ E-26 171.541/02 and FAPERJ E-26/103.097/2008).

\section{REFERENCES}

Almeida C.M.C., Kanashiro M.M., Rangel Filho F.B., Matta M.R.F., Kipnis T.L. \& Silva W.D. 1998. Development of snake antivenom antibodies in chickens and their purification from yolk. Vet. Rec. 143:579-584.

Almeida C.M., Quintana-Flores V.M., Medina-Acosta E., Schriefer A., Barral-Netto M. \& Silva W.D. 2003. Egg yolk anti-BfpA antibodies as a tool for recognizing and identifying enteropathogenic Escherichia coli. Scand. J. Immunol. 57(6):573-82.

Berryessa N.A., Marks S.L., Pesavento P.A., Krasnansky T., Yoshimoto S.K., Johnson E.G. \& Grooters A.M. 2008. Gastrointestinal pythiosis in 10 dogs from California. J. Vet. Intern. Med. 22:1065-1069.

Brunda G., Sashidar R.B. \& Sarin R.K. 2006. Use of egg yolk antibody $(\lg Y)$ as an immunological tool in the detection of Indian cobra (Naja naja naja) venom in biological samples of forensic origin. Toxicon 48(2):183-194.

Bosco S.M.G., Bagagli E., Candeias Jr J.P.A., Franco J.M.G., Marques M.F., Mendoza L., Camargo R.P. \& Marques S.A. 2005. Human Pythiosis, Brazil. Emm. Infec. Dis. 11(5):715-718.

Carlander D., Stalberg J. \& Larsson A. 1999. Chicken antibodies: A clinical chemistry perspective. Upsala J. Med. Sci. 104:179-190.

Chaffin M.K, Schumacher J. \& McMullan W.C. 1995. Cutaneous pythiosis in the horse. Vet. Clin. North Am., Dermatol. Equine Pract. 11(1):91-103.
Chindamporn A., Vilela R., Hoag K.A. \& Mendoza L. 2009. Antibodies in the sera of host species with pythiosis recognize a variety of unique immunogens in geographically divergent Pythium insidiosum strains. Clin. Vaccine Immunol. 16(3):330-336.

Davis D.J., Lanter K., Makselan S., Bonati C., Asbrock P., Ravishankar J.P. \& Money N.P. 2006. Relationship between temperature optima and secreted protease activities of three Pythium species and pathogenicity toward plant and animal hosts. Mycol. Res. 110:96103.

De Cock A.W.A.M., Mendoza L., Padhye A.A., Ajello L. \& Kaufman L. 1987. Pythium insidiosum sp. nov., the etiologic agent of pythiosis. J. Clin. Microbiol. 25:344-349.

Dong L.V., Quyen L.K., Eng K.H. \& Gopalakrishnakone P. 2003. Immunogenicity of venoms from four common snakes in the South of Vietnam and development ELISA kit for venom detection. J. Immunol. Method 282:13-31.

Erhard M.H., Gobel E., Lewan B., Losch U. \& Stangassinger M. 1997. Systemic availability of bovine immunoglobulin $\mathrm{G}$ and chicken immunoglobulin $\mathrm{Y}$ after feeding colostrum and whole egg powder to newborn calves. Arch. Tierernähr. 50(4):369-380.

Gabriel A.L., Kommers G.D., Trost M.E., Barros C.S.L., Pereira D.B., Schwendler S.E. \& Santurio J.M. 2008. Surto de pitiose cutânea em bovinos. Pesq. Vet. Bras. 28(12):583-587.

Grecco F.B., Schild A.L., Quevedo P., Assis-Brasil N.D. \& Kommers G.D., Marcolongo-Pereira C. \& Soares M.P. 2009. Pitiose cutânea em bovinos na região Sul do Rio Grande do Sul. Pesq. Vet. Bras. 29(11):938-942.

Krajaejun T., Kunakorn M., Pracharktam R., Chongtrakool P., Sathapatayavongs B., Chaiprasert A., Vanittanakom N., Chindamporn A. \& Mootsikapun P. 2006. Identification of a novel 74-kiloDalton immunodominant antigen of Pythium insidiosum recognized by sera from human patients with pythiosis. J. Clin. Microbiol. 44(5):16741680.

Kunavisarut S., Nimvorapan T. \& Methasiri S. 2003. Pythium corneal ulcer in Ramathibodi Hospital. J. Med. Assoc. Thai 86(4):338-342.

Laemmli U.K. 1970. Cleavage of structural proteins during the assembly of the head of bacteriophage T4. Nature 227(259):680-685.

Leal A.T., Santurio J.M., Leal A.B.M., Catto J.B., Flores E.F., Lubeck I. \& Alves S.H. 2005. Characterization of the specificity of the humoral response to Pythium insidiosum antigens. J. Med. Mycol. 15(2):6368.

Mendoza L., Mandy W. \& Glass R. 2003. An improved Pythium insidiosum-vaccine formulation with enhanced immunotherapeutic properties in horses and dogs with pythiosis. Vaccine 21: 2797-804.

Mendoza L., Villalobos J., Callejas C.E. \& Solis A. 1992a. Evaluation of two vaccines for the treatment of pythiosis insidiosi in horses. Mycopathologia 119:89-95.

Mendoza L. Nicholson V. \& Prescott J.F. 1992b. Immunoblot analysis of the humoral immune response to Pythium insidiosum in horses with pythiosis. J. Clin. Microbiol. 30(11):2980-2983.

Mendoza L. \& Alfaro A.A. 1996. Equine Pythiosis in Costa Rica: Report of 39 cases. Mycopathologia 94:123-129.

Pesavento P.A., Barr B., Riggs S.M., Eigenheer A.L., Pamma R. \& Walker R.L. 2008 Cutaneous pythiosis in a nestling white-faced ibis. Vet. Pathol. 45:538-541.

Pier A.C., Cabanes F.J., Chermette R., Ferreiro L., Guillot J., Jensen H.E. \& Santurio J.M. 2000. Prominent animal mycosis from various regions of the world. Med. Mycol. 38(1):47-58.

Reis Jr J.L., Carvalho E.C.Q., Nogueira R.H.G., Lemos L.S., Mendoza L. 2003. Disseminated pythiosis in three horses. Vet. Microbiol. 96:289295.

Remfry J. 1985. Ethical committees and animal experimentation. Vet. Rec. 117(19):508. 
Schade R., Henklein P. Hlinak A., Vent J.D. \& Steinbusch H. 1996. Specificity of chicken (IgY) versus rabbit (IgG) antibodies raised against cholecystokinin octapeptide (CCK-8). Altex 13(5):80-85.

Santurio J.M., Monteiro A.B., Leal A.T., Kommers G.D., De Sousa R.S. \& Catto J.B. 2004. Cutaneous Pythiosis insidiosi in calves from the Pantanal region of Brazil. Mycopathologia 141(3):123-125.

Santurio J.M., Leal A.T., Leal A.B.M., Festugatto R., Lubeck I., Sallis E.S.V., Copetti M.V., Alves S.H. \& Ferreiro L. 2003. Three types of immunotherapics against pythiosis insidiosi developed and evaluated. Vaccine 21:1-6.

Su Y.C. \& Wong A.C. 1995. Identification and purification of a new staphylococcal enterotoxin, H. Appl. Environ. Microbiol. 61:1438.

Tabosa I.M., Riet-Correa F., Nobre V.M., Azevedo E.O., Reis-Junior J.L. \& Medeiros R.M. 2004. Outbreaks of pythiosis in two flocks of sheep in northeastern Brazil. Vet. Pathol. 41(4):412-415.

Thianprasit M., Chaiprasert A. \& Imwidthaya P. 1996. Human pythiosis. Curr. Top. Med. Mycol. 7(1):43-54.

Van Nguyen S., Umeda K., Yokoyama H., Tohya Y. \& Kodama, Y. 2006. Passive protection of dogs against clinical disease due to Canine parvovirus-2 by specific antibody from chicken egg yolk. Can. J. Vet. Res. 70(1):62-4.

Vanittanakom N., Supabandhu J., Khanwan C., Praparattanapan J., Thirach S., Prasertwitayakij N., Louthrenoo W., Chiewchanvit S. \& Tananuvat N. 2004. Identification of emerging human-pathogenic Pythium insidiosum by serological and molecular assay-based methods. J. Clin. Microbiol. 42(9):3970-3974.

Vieira-da-Motta O., Medina-Acosta E., Almeida C.M.C., Kipnis T.L. \& Silva W.D. 2001a. Development of anti-Staphylococcus aureus enterotoxins antibodies in chickens and their purification from yolk. Scand. J. Immun. 54(Suppl.1):117.

Vieira-da-Motta O., Damaceno P.R., Silva W.D. \& Medina-Acosta E. 2001b. RNAIII Inhibiting Peptide (RIP) inhibits agr-regulated toxin production. Peptides 22(10):1621-1627.

Warr G.W., Magor K.E. \& Higgins D.A. 1995. IgY: Clues to the origins of modern antibodies. Immun. Today 16(8):392-398.

Wellehan J.F., Farina L.L., Keoughan C.G., Lafortune M., Grooters A.M., Mendoza L., Brown M., Terrell S.P., Jacobson E.R. \& Heard D.J. 2004. Pythiosis in a dromedary camel (Camelus dromedarius). J. Zoo Wildl. Med. 35(4):564-568. 